Marine Chemistry

January 2006; 98(1) : 1-17

http://dx.doi.org/10.1016/j.marchem.2005.06.001

(C) 2005 Elsevier B.V. All rights reserved
Archimer, archive institutionnelle de l'Ifremer http://www.ifremer.fr/docelec/

\title{
Heavy metals distribution in mangrove sediments along the mobile coastline of French Guiana
}

\author{
C. Marchand ${ }^{a^{\star}}$, E. Lallier-Vergès ${ }^{a}$, F. Baltzer ${ }^{b}$, P. Albéric ${ }^{a}$, D. Cossa ${ }^{c}$ and P. Baillif ${ }^{a}$ \\ anstitut des Sciences de la Terre d'Orléans, UMR 6113 CNRS-UO, Université d'Orléans, Géosciences, 45067 \\ Orléans, France

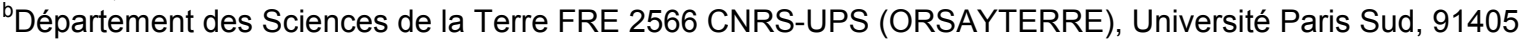 \\ Orsay, France \\ 'Institut Français de Recherche pour l'Exploitation de la Mer (IFREMER), BP 21105, F 44311 Nantes cedex 03 , \\ France \\ *: Corresponding author : cyril.marchand@univ-orleans.fr
}

\begin{abstract}
The accumulation of nine heavy metals in fine-grained sediments from the mangrove fringed coast of French Guiana is evaluated. The dynamic features of the South American tropical coastline, from the Amazon to the Orinoco Rivers, result in mangrove sediments being alternately submitted to phases of erosion and net sedimentation a few tens of years long. This process influences the distribution of the heavy metals associated with these frequently re-mobilized deposits. Sedimentary cores and mangrove plant samples were collected, at different seasons, in various swamps characterized by different properties (content of sedimentary organic matter, distance from sea water and fresh water). The ranges of measured concentrations expressed in $\mu \mathrm{mol} g-1$ were the following: $\mathrm{Cu}(0.06$ to 0.61$)$, $\mathrm{Co}(0.12$ to 0.68$), \mathrm{Pb}(0.08$ to 0.18$), \mathrm{Ni}(0.32$ to 0.76$), \mathrm{Cr}(0.61$ to 1.40$), \mathrm{Zn}$ (1.25 to 5.94), Mn (4.36 to 45.4) and Fe (441 to 1128). No differences were found between sediments from mangroves developing upstream and downstream of urban areas, i.e. Cayenne and Kourou. This suggests that the content of mangrove sediments in heavy metals along the coastline of French Guiana is essentially the result of the continuous alternation of accumulation and transport phases occurring upstream after departing from the Amazon watershed. The sources of this heavy metals content are thus difficult to identify. However it is well known that the alluvium produced by the natural erosion of the Amazonian soils is naturally enriched in mercury. Also, the run-off from gold mining activities is known to contribute to mercury pollution. Ranges in total $\mathrm{Hg}$ were between 0.15 and 2.57 $\mathrm{nmol} g-1$, with mean values close to $0.41 \mathrm{nmol} g-1$, and were clearly correlated with total organic carbon except for some outstanding high values, which may be a result of rapid geochemical changes. Heavy metal concentrations showed variations with depth. The redox conditions and the decay processes affecting the organic matter control the cycling of iron and manganese, which in turn control the concentrations and associations of heavy metals. These preliminary results suggest that the variations in heavy metal content with depth or between mangrove areas result largely from diagenetic processes rather than changes in metal input resulting from local human activities.
\end{abstract}

Keywords: Heavy metals; Fe/Mn cycling; Mangrove; French Guiana 
Heavy metals distribution in mangrove sediments along the mobile coastline of French Guiana.

\section{Marchand*}

Institut des Sciences de la Terre d'Orléans, UMR 6113 CNRS-UO, Université d'Orléans, Géosciences, 45067 Orléans, France.

\section{E. Lallier-Vergès}

Institut des Sciences de la Terre d'Orléans, UMR 6113 CNRS-UO, Université d'Orléans, Géosciences, 45067 Orléans, France.

\section{F. Baltzer}

Departement des Sciences de la Terre FRE 2566 CNRS-UPS (ORSAYTERRE), Université Paris Sud, 91405 Orsay, France.

\section{P. Albéric}

Institut des Sciences de la Terre d'Orléans, UMR 6113 CNRS-UO, Université d'Orléans, Géosciences, 45067 Orléans, France.

\section{Cossa}

Institut Français de Recherche pour l'Exploitation de la Mer, BP 21105, F 44311 Nantes cedex 03,

France

\section{P. Baillif}

Institut des Sciences de la Terre d'Orléans, UMR 6113 CNRS-UO, Université d'Orléans, Géosciences, 45067 Orléans, France.

*Corresponding author

E-mail address: cyril.marchand@univ-orleans.fr

Running Head: Heavy metal distribution in mangrove sediments. 


\section{Abstract}

The accumulation of nine heavy metals in fine-grained sediments from the mangrove fringed coast of French Guiana is evaluated. The dynamic features of the South American tropical coastline, from the Amazon to the Orinoco Rivers, result in mangrove sediments being alternately submitted to phases of erosion and net sedimentation a few tens of years long. This process influences the distribution of the heavy metals associated with these frequently re-mobilized deposits. Sedimentary cores and mangrove plant samples were collected, at different seasons, in various swamps characterized by different properties (content of sedimentary organic matter, distance from sea water and fresh water). The total concentrations of $\mathrm{Fe}, \mathrm{Mn}, \mathrm{Cr}, \mathrm{Cu}, \mathrm{Co}, \mathrm{Ni}, \mathrm{Pb}, \mathrm{Zn}$ were determined by the microwave digestion technique combined with HR-ICP-AES detection. The total Hg concentrations were measured using the cold vapor technique coupled with an AAS detector. The ranges of measured concentrations expressed in $\mu \mathrm{mol} \mathrm{g}{ }^{-1}$ were the following: $\mathrm{Cu}$ (0.06 to 0.61$), \mathrm{Co}(0.12$ to 0.68$), \mathrm{Pb}(0.08$ to 0.18$), \mathrm{Ni}(0.32$ to 0.76$), \mathrm{Cr}(0.61$ to 1.40$)$ and $\mathrm{Zn}$ (1.25 to 5.94$)$. No differences were found between sediments from mangroves developing upstream and downstream of urban areas, i.e. Cayenne and Kourou. This suggests that the content of mangrove sediments in heavy metals along the coastline of French Guiana is essentially the result of the continuous alternation of accumulation and transport phases occurring upstream after departing from the Amazon watershed. The sources of this heavy metals content are thus difficult to identify. However it is well known that the alluvium produced by the natural erosion of the Amazonian soils is naturally enriched in mercury. Also, the run-off from gold mining activities is known to contribute to mercury pollution. Ranges in total $\mathrm{Hg}$ were between 0.15 and $2.57 \mathrm{nmol} \mathrm{g}^{-1}$, with mean values close to $0.41 \mathrm{nmol} \mathrm{g}^{-1}$, and were clearly correlated with total organic carbon except for some outstanding high values, which may be a result of rapid geochemical changes. Heavy metal concentrations showed variations with depth. The redox conditions and the decay processes affecting the organic matter control the cycling of iron and manganese, which in turn control the concentrations and associations of heavy metals. These preliminary results suggest that the variations in heavy metal content with depth or between mangrove areas result largely from diagenetic processes rather than changes in metal input resulting from local human activities. 
Keywords: Heavy metals, Fe/Mn cycling, Mangrove, French Guiana

\section{Introduction}

The cycling of heavy metals, because of their toxicity, bio-accumulation capacity and persistence, is a serious question recently addressed by many studies on mangrove environments (Harbison, 1986; Lacerda et al., 1988; Mackey and Hodgkinson, 1995; Tam and Wong, 1995, 1997, 2000; Clark et al., 1998). In contrast with organic pollutants, heavy metals cannot be biologically or chemically degraded, and thus may either accumulate locally or be transported over long distances. In natural environments, the associations of metals and their distributions depend on various parameters including redox conditions (Guo et al., 1997) and organic contents (Nissenbaum and Swaine, 1976; Mounier et al., 2001). These parameters may influence the toxicity of metals through processes like mercury methylation (Mason et al., 1994), and by controlling their availability for living organisms. In addition, metals can be adsorbed onto the surface of minerals, like clay minerals, Fe and/or Mn oxihydroxides (Dong et al., 2000; Quémerais et al., 1998). Consequently, high concentrations of heavy metals can accumulate in sediments, and especially in fine-grained oozes, which present high mineral specific surfaces. Mangrove ecosystems, developing in the intertidal zone of most tropical and subtropical regions, are characterized by major contrasts in redox conditions and high rates of organic carbon accumulations (Huc, 1980). They may act as a sink or a source of heavy metals in coastal environments because of their variable physical and chemical properties (Harbison, 1986). Moreover, many countries have decided to use mangroves in the treatment of sewage effluents. Mangroves of French Guiana are unique due to their proximity to the Amazon River and the highly dynamic feature of their coastline. The Amazon discharge partly migrates northwestward in the form of mudwaves moving towards the Orinoco River, following the direction of both the current of the Guianas (Allison et al., 2000) and the coastal dynamic influences. The components of mangrove deposits can be stabilized for a few decades, like sand grains in a major dune, until they are reset in suspension when erosion reaches their settling place. Many studies, regarding heavy-metal pollution, have been done to the south of the Amazon River (Silva et al., 1998; Lacerda et al., 1999; Machado et al., 2002 a,b). 
However few data concern the coastline of the Guianas and its specific system. The present study aims at determining the distribution of various heavy metals (Fe, $\mathrm{Mn}, \mathrm{Cr}, \mathrm{Cu}, \mathrm{Co}, \mathrm{Ni}, \mathrm{Pb}, \mathrm{Zn}$ and $\mathrm{Hg}$ ) in mangrove sediments and plants, and to estimate a possible local human input by comparing sediments upstream and downstream of urban areas, i.e. Cayenne and Kourou. Our second intent was to assess the relationships of these heavy metals with sedimentary organic matter and pore water properties (redox, $\mathrm{pH}$ ), which were measured in a previous study (Marchand et al., 2004). Quantitative analyses were carried out on samples of mangrove species and sedimentary cores collected in 7 mangrove areas of French Guiana selected as a function of both their species and the stages of their development, i.e. young, mature, senescent and recolonized areas.

\section{Materials and Methods}

\section{Study site}

The mangroves studied are located: i) at the mouth of the Kaw River, $30 \mathrm{~km}$ southeast of Cayenne, ii) on the right bank of the Sinnamary River, $50 \mathrm{~km}$ northwest of Kourou, French Guiana (Fig. 1). These mangroves develop on huge mud banks, $30 \mathrm{~km}$ long (total length of one bank) and can be up to $5 \mathrm{~km}$ wide during low tide. These mangrove forests, not subject to anthropogenic exploitation, are predominantly colonized by Avicennia germinans; however scarce Laguncularia racemosa fringe the seashore as also does Crenea maritima. Some Acrostichum aureum ferns develop in the senescent mangroves, and Rhizophora mangle stands develop in sheltered areas (K2 and K3). The higher topography of the mature mangrove area prevents all but spring tides flooding their ground and so reaching the soil of the mature (S4) and senescent mangroves (S3). As a consequence, daily tidal inundation only reaches the outer margin, i.e. the younger stages of these mangrove swamps (S1 and S2). Due to the systematic erosional features of this coastline, adult Avicennia trees are frequently submitted to a sudden accretion that buries their pneumatophores system with a several tens of centimeters thick mud cover. This choking process results in a dead standing forest. These areas are subsequently recolonized and young live trees co-exist with standing dead trees, a situation called "recolonized cemetery mangrove" (S2). 


\section{Field Sampling}

Cores were collected at low tide with an Eijkelkamp gouge auger in 7 mangroves defined in terms of vegetation-species composition and stages of development, and in shoreface sediments, i.e. sediments devoid of vegetation. Work was carried out during two fieldtrips, in July 2001 and January 2002. S1, S2 and S3 were collected in July, i.e. the end of the rainy season; S4, K1, K2 and K3 were collected in January, i.e. the beginning of the rainy season. In the A. germinans forests, core locations were chosen equidistant from trees, in consideration of the large extension of the radial cable roots. In R. mangle forests, cores were collected under prop roots. After being collected, cores were wrapped in plastic film and aluminum foil in order to limit gaseous exchanges. Samples were kept refrigerated before analyses. Measurements of physicochemical parameters ( $\mathrm{pH}$, redox, dissolved sulphides) and pore water extraction were performed in an air-conditioned laboratory, on the day of coring. Briefly, probes were inserted in the center of the core, in order to avoid modification resulting from contact with atmospheric gas, and left until equilibrium was reached as described in Marchand et al. (2004). In mangrove sediments, pore water extraction may be very laborious due to the fine-grained nature of the sediment and the roots density. In order to precisely define the depth intervals, pore waters were extracted using centrifuge rather than in situ peepers (Gribsholt and Khristensen, 2002). Centrifugation was done on the very day of coring as recommended by Albéric et al. (1996) in order to avoid enrichment in colloidal material (Chin and Gschwend, 1991). Centrifugation was done at $5000 \mathrm{rpm}$ for $20 \mathrm{~min}$. All samples were filtered through $0,45 \mu \mathrm{m}$ Sartorius ${ }^{\circledR}$ filters under pressure and acidified to pH 2 with Suprapur ${ }^{\circledR} \mathrm{HNO}_{3}$. Samples were stored in cleaned $14 \mathrm{ml}$ polypropylene tubes, in a cold room $\left(\mathrm{T}=4^{\circ} \mathrm{C}\right)$ until analyses.

\section{Carbon and sulphur analyses}

Carbon and sulphur analyses were conducted by combustion at $1100^{\circ} \mathrm{C}$ with a CNS-2000 LECO $^{\circledR}$ apparatus. Due to the nearly total lack of carbonates (samples were tested with $\mathrm{HCl}$ ), total carbon can be attributed to the total organic carbon. Samples were taken at the following depthintervals (in $\mathrm{cm}$ ): $2 \mathrm{~cm}$ from 0 to $20 \mathrm{~cm}, 5 \mathrm{~cm}$ from 20 to 60 then every $20 \mathrm{~cm}$ and kept refrigerated. 
TOC are reported in Marchand et al. (2004) Samples for heavy metals analyses were chosen in relation to TOC profiles. TOC and TS given herein are mean values from duplicate cores.

\section{Heavy metal determinations}

Sediment and plant samples were dried and ground with an agate pestle and mortar. The concentrations of $\mathrm{Fe}, \mathrm{Mn}, \mathrm{Cr}, \mathrm{Cu}, \mathrm{Co}, \mathrm{Ni}, \mathrm{Pb}$, and $\mathrm{Zn}$ were determined on a Jobin-Yvon ${ }^{\circledR} \mathrm{HR}-\mathrm{ICP}-$ AES after microwave digestion. A $10 \mathrm{ml}$ volume of a mixture of Suprapur ${ }^{\circledR} \mathrm{HCl}, \mathrm{HNO}_{3}$ and $\mathrm{H}_{2} \mathrm{O}$ was added to $100 \mathrm{mg}$ of sample. The whole was placed in Teflon vessels, previously washed with concentrated nitric acid. Samples were digested in a MDS 2000 (CEM Corp. ${ }^{\circledR}$ ) microwave at $100 \%$ power with pressure set at 120 psi for $20 \mathrm{~min}$, the overall digestion time for the one cycle was $40 \mathrm{~min}$. Blank mixture acid was digested in the same way. HR-ICP-AES detection limits are expressed as three times the standard deviation determined from numerous analyses of blanks (Tab. 1). Each sample was

measured in triplicate with mean standard deviation for $\mathrm{Fe}, \mathrm{Mn}, \mathrm{Cr}, \mathrm{Cu}, \mathrm{Co}, \mathrm{Ni}, \mathrm{Pb}, \mathrm{Zn}$ less than 2, 1, $2,5,5,5,10$, and $2 \%$ respectively. Quality control were performed by analysis of certified reference materials of estuarine sediments (LGC 6137). Analytical results obtained for references materials differed by less than $15 \%$ from the certified values (Tab. 1). Dissolved Fe and Mn concentrations were also measured in triplicate on acidified pore water samples with the same Jobin-Yvon ${ }^{\circledR}$ HR-ICPAES.

Total $\mathrm{Hg}(\mathrm{HgT})$ from sediment and plant samples were determined using an Altec ${ }^{\circledR}$ Advanced Mercury Analyzer (AMA 254). This analyzer is a single purpose atomic absorption spectrophotometer. $30 \mathrm{mg}$ of sample is burned at $550^{\circ} \mathrm{C}$ under oxygen flow, mercury effluents are trapped in an amalgamator containing gold, subsequently released and transferred to measuring cuvettes. The detection limit and mean standard deviation are close to $0.035 \mathrm{nmol} \mathrm{g}^{-1}$, and $7 \%$ respectively (Cossa et al., 2002).

\section{Results and Discussion}


Accumulation of heavy metals in sediments

The average concentrations of some heavy metals $(\mathrm{Cu}, \mathrm{Co}, \mathrm{Cr}, \mathrm{Ni}, \mathrm{Pb}, \mathrm{Zn}, \mathrm{Hg}, \mathrm{Fe}$ and $\mathrm{Mn})$ from mangrove sediments in Sinnamary and Kaw mangroves, and from unvegetated sediments are given in Tab. 2 along with their respective ranges. In Sinnamary, mean heavy metal concentrations were $\left(\mu \mathrm{mol} \mathrm{g}{ }^{-1}\right)$ : $\mathrm{Fe}(789.29)>\mathrm{Mn}(9.82)>\mathrm{Zn}(2.51)>\mathrm{Cr}(1.15)>\mathrm{Ni}(0.54)>\mathrm{Co}(0.32)>\mathrm{Cu}(0.28)$ $>\mathrm{Pb}(0.13)>\mathrm{Hg}\left(0.41 \mathrm{nmol} \mathrm{g}^{-1}\right)$.

Hong Kong mangroves, receiving industrial, livestock and domestic sewage were considered as seriously contaminated by Tam and Wong (2000), reporting higher concentrations in $\mathrm{Pb}$ and $\mathrm{Cu}$ but similar concentrations in $\mathrm{Zn}$ and lower concentrations in Cr. Along the industrial Brisbane estuary (Australia), mangroves were considered as moderately polluted with similar concentrations of $\mathrm{Ni}, \mathrm{Cu}$, $\mathrm{Pb}$ and lower concentrations in $\mathrm{Cr}$ and $\mathrm{Zn}$ (Mackey and Hodgkinson, 1995). Close to the same mangroves and near a refuse tip, Clark et al. (1998) reported similar or higher concentrations in $\mathrm{Pb}, \mathrm{Cu}$ and $\mathrm{Ni}$, and lower concentrations of $\mathrm{Zn}$ and $\mathrm{Cr}$. All these mangrove swamps were moderately contaminated, but pollution levels can be far more serious. For example, in a Brazilian mangrove submitted to landfill run-off during two decades, Machado et al. (2002a) reported metal levels that were up to $4.4 \mathrm{nmol} \mathrm{g}^{-1}$ dry wt $\mathrm{Hg}, 13 \mu \mathrm{mol} \mathrm{g}{ }^{-1}$ dry wt $\mathrm{Zn}$, and $0.91 \mu \mathrm{mol} \mathrm{g} \mathrm{g}^{-1}$ dry wt $\mathrm{Cu}$. Consequently, heavy metal concentrations of Guiana's mangroves, which were not used as refuse tip, were surprisingly similar to mangroves located close to anthropogenic sources of pollution and considered by some authors as moderately contaminated.

Results also revealed that mean values of heavy metal concentrations in mangrove sediments were similar in Sinnamary and in Kaw, which respectively are upstream and downstream of urban areas (Cayenne and Kourou) (Tab. 2). This second result suggests that local anthropogenic metal input from French Guiana was insignificant or that this input was rapidly diluted into the huge mass of sediments migrating along the coast.

Finally, the most surprising result was that concentrations in mangrove sediments were similar, e.g. $\mathrm{Ni}, \mathrm{Co}$, or lower than in the unvegetated sediments, e.g. Mn 9.7 and $18.9 \mu \mathrm{mol} \mathrm{g}^{-1}$ respectively. $\mathrm{Hg}$ and Zn were the only metals that were more concentrated in mangroves sediments (see next chapters for $\mathrm{Hg}$ ). This result suggests that mangrove did not act like a trap in this specific system. The uniqueness 
of the coastline of the Guianas results from its dynamic features. The Amazon discharge partially migrates in the form of mudwaves northwestward to the Orinoco River, following the current of the Guianas (Allison et al., 2000). The mudbanks on which mangroves develop move rapidly along the coast, being eroded on their windward side and accreting on their lee side. During this process, mangrove deposits can be stabilized during a few decades and then be eroded, put in suspension and re-sedimented downstream, carrying with them their heavy metal content. Gaillardet et al. (1997), in a study concerning the Amazon River basin, presented concentrations in the suspended sediments of the Amazon mainstreams close to, or a bit higher than our values (Tab. 2). We thus suggest that the heavy metal contained in unvegetated and in mangrove sediments along the French Guiana coastline results from the continuous addition in upstream regions, including the Amazon watershed, and transport. This mobile mud belt can be considered as a massive, suboxic bed reactor (Aller, 1998), the repetitive redox successions and multiple reoxidation may induce dissolution of some forms of heavy metals and then may explain the lower concentrations in sediments from French Guiana than in the Amazon River suspended material. In addition, the specific redox conditions (suboxic to oxic) occurring in the $A$. germinans swamps may also explain the lower concentrations in mangrove sediments than in unvegetated sediments (see next paragraphs).

However, rivers flowing along urban areas, may bring the corresponding pollutants to the downstream estuarine sediments, from where they are incorporated in the mudbank cycle. This process may result downstream in an increased accumulation and in higher concentrations.

In contrast with metal distribution in shoreface sediments, which were stable with depth, the concentrations in mangrove swamps occasionally showed large changes. The subsequent discussion is focused on vertical trends in four Avicennia mangrove swamps from the Sinnamary area, each characterized by a different stage of forest evolution, sedimentary organic content, distance from shore, and collection season. The various developmental stages of the Avicennia-dominated mangrove of Sinnamary have been previously described relative to their structural and biological features (Fromard et al., 1998).

Redox sensitive element $\mathrm{Fe}, \mathrm{Mn}$. 
The geochemical behaviors of iron and manganese are coupled since these elements are both highly redox sensitive (Lacerda et al., 1999; Mortimer and Rae, 2000). Mean Fe and Mn concentrations in the solid phase were lower in mangrove sediments than in the shoreface ones while the mineralogical composition was essentially the same (cf. next chapter), suggesting that the geochemical processes, which happened in mangrove sediments, induced dissolution of some forms of Fe and Mn.

In the young Avicennia and the "recolonized cemetery" mangrove swamps of French Guiana suboxic to oxic processes continuously lead to Eh values averaging $300 \mathrm{mV}$ between 5 and $30 \mathrm{~cm}$ depth and reaching up to $450 \mathrm{mV}$ (Marchand et al., 2004) (Fig. 2, 3). These conditions are associated with a low content in sedimentary organic matter, daily tidal inundation and exchange and by the high propensity of young Avicennia germinans to aerate the sediment at the root level between 5 and $30 \mathrm{~cm}$ deep (Scholander et al., 1955). In this level, dissolved concentrations of Mn and Fe decreased dramatically, while they increased in the solid phase, probably through precipitation in the form of oxi-hydroxides (Fig. $3 \mathrm{~d}, \mathrm{f}$ ). In the anoxic upper $5 \mathrm{~cm}$, in which Eh values were close to $100 \mathrm{mV}, \mathrm{Fe}$ and $\mathrm{Mn}$ were present in the soluble form, reaching concentrations of up to $180 \mu \mathrm{moll}^{-1}$ and $1120 \mu \mathrm{moll}^{-1}$, respectively (Fig. 2 c, d). These high concentrations reflect the reduction of Mn and Fe oxi-hydroxides by bacteria, using them as electron acceptors in the reaction of organic matter decay. Below $30 \mathrm{~cm}$ deep, sediments were again anoxic and non-sulphidic; accordingly, concentrations in $\mathrm{Mn}$ and $\mathrm{Fe}$ in the dissolved phase slightly increased in comparison with the upper level.

In the "recolonized cemetery" mangrove, results in physico-chemical properties largely differ from what has been described before. At the time of the field work, below $30 \mathrm{~cm}$ deep, the buried roots of standing dead trees were found to be slowly degrading in an anaerobic environment in which sulphate reduction occurred (Marchand et al., 2004). Sulphate reduction leads to sulphide precipitation in this zone, with total solid sulphur reaching more than $1 \%$ (Fig. 3 c). As soon as sulphate-reduction began, dissolved $\mathrm{Fe}$ concentrations decreased, reflecting the co-precipitation of $\mathrm{Fe}$ and $\mathrm{S}$ in the form of framboïdal pyrite (optically observed in a previous study, Marchand et al., 2003) and probably also greigite. Pyrite is an important sink for trace metals since many of them are incorporated during its formation (Boulègue et al., 1982). Huerta-Diaz and Morse (1992), in their study of the pyritization of 
trace metals in anoxic marine sediments found that incorporation into pyrite was high for $\mathrm{Hg}$, moderate for $\mathrm{Co}, \mathrm{Mn}, \mathrm{Cu}$, and $\mathrm{Ni}$ and low for $\mathrm{Cr}, \mathrm{Pb}$ and $\mathrm{Zn}$. We may suppose that similar behavior prevail in mangrove sediments (Aragon and Miguens, 2001). Mn, in spite of being present in the soluble form, did not precipitate at the buried root level so that no correlation with $\mathrm{S}$ were observed, possibly because Mn-sulphides minerals such as alabandite are undersaturated or another phase, for example Mn-carbonate, is more stable. In contrast, solid Mn increased in the low Eh zone beneath the sulphate reducing zone, i.e. $50 \mathrm{~cm}$ deep, probably in the form of carbonates.

In the older mangroves, characterized by a higher organic content and exempt from daily tidal inundation, the depth evolution of redox potentials was clearly different than in the younger stages and controlled by seasons (Marchand et al., 2004). During the rainy season, below $5 \mathrm{~cm}$ depth, the whole depth profile was anoxic, with Eh values $<100 \mathrm{mV}$ (Fig. 4 b). Nevertheless, the concentrations of dissolved $\mathrm{Fe}$, far from increasing as a consequence of the reduction of $\mathrm{Fe}$ in soluble form, decreased with depth (Fig. 4 c). In addition, soluble sulphides were below the detection limit except between 30 and $40 \mathrm{~cm}$ depth of the older swamps (Marchand et al., 2004). This phenomenon probably reflected the co-precipitation of Fe with the sulphides produced by the reduction of sulphate (Fig. 4 c), as observed in the lower part of the core collected in "recolonized cemetery" mangrove.

During dry conditions, the desiccation of the upper sediment adds its oxidation effects to those of root activity. As a result, oxic to suboxic processes dominate in the upper $20 \mathrm{~cm}$, with Eh values ranging from 200 to $500 \mathrm{mV}$ (Marchand et al., 2004) and a zone of sulphate reduction underlies a zone of sulphide oxidation. When the rainy season comes again, a three layer diagenetic column is rapidly formed (Fig. 5 b). The oxidation of sulphides leads to very low $\mathrm{pH}$ and induces a release of Fe and Mn in the soluble phase, resulting in Mn dissolved concentrations up to $200 \mu \mathrm{moll}^{-1}$, and in huge dissolved Fe concentrations up to $5000 \mu$ moll $^{-1}$, reflecting the oxidation of pyrite. Below, $25 \mathrm{~cm}$ depth, the sediment was anoxic and iron precipitated in the layer of sulphate reduction, while manganese increased in the solid phase by the depth of $60 \mathrm{~cm}$, with a maximum higher than $0.2 \%$ (Fig. $5 \mathrm{~d}$ ). Consequently in all the mangrove swamps studied here, solid phase Mn increased at depth. Considering the anaerobic conditions characterizing these layers and the likely high alkalinity, with high salinity (Marchand et al., 2004), we suggest that Mn was in the form of carbonates. Zhu et al. 
(2002) described mixed $\mathrm{Ca}, \mathrm{Mg}, \mathrm{Fe}, \mathrm{Mn}$ authigenic carbonates upstream the mobile muds of the coast of the Guianas. Subtidal and intertidal deposits of the Sinnamary mudwave are often supersaturated with respect to rhodochrosite a few centimeters below the sediment surface (Aller et al., 2004). It is difficult to distinguish between in situ precipitation at depth and dissolution in the upper layer of inherited carbonate from shoreface sediments, both may occur. However, considering that $\mathrm{Mn}$ concentrations were higher in the unvegetated sediment than in the upper sediment from every mangrove swamps, we suggest that the oxic to suboxic and low $\mathrm{pH}$ (sulphide oxidation) conditions that may occur in the upper layer, induces dissolution of carbonates. The Mn concentrations at depth may reflect in part the nature of the original sediments before mangrove development. This process may also explain lower concentrations of some heavy metals in mangrove than in shoreface sediments. However in the older swamps, we suggest that both dissolution and precipitation may occur since the depth of the boundary between suboxic and anoxic layers strongly migrates during the year. It is noteworthy that the higher solid Mn concentrations were correlated with the lower solid S values, and that below this Mn rich layer, solid Mn decreased while solid S increased again. This observation suggests that the possibility of methanogenesis, which can occur when sulphate is consumed, has to be also considered, although it has been rarely described in mangrove environments (Giani et al., 1996). The cycling of $\mathrm{Fe}, \mathrm{Mn}$, and $\mathrm{S}$ are summarized in a schematic diagram (Fig. 6) describing their evolution with respect to seasons and forest development.

\section{Diagenetic evolution of the other metals}

Many factors may influence the ways in which heavy metals are incorporated in mineral species, as well as distributed and concentrated in mangrove swamps. In the following discussion we will try to analyze the respective influences of the redox driven Fe, Mn cycling, the mineralogical composition of the substrate, and the organic matter content.

On the one hand, in the senescent swamps, many metals were peaking in the solid phase at the maximum of sulphur precipitation, a point easily explained by co-precipitations with sulphides. (Fig. 4 e, f, g). On the other hand, in the upper oxic layer of the "recolonized cemetery", co-precipitation with oxi-hydroxides may explain that many metals were at a maximum in the solid phase (Fig. $3 \mathrm{~d}, \mathrm{f}, \mathrm{g}$ ). 
Many authors have reported the strong links between $\mathrm{Fe}$ and Mn cycling and trace metals. Under suboxic conditions, $\mathrm{Pb}$, Ni and Co can be easily adsorbed on Mn oxides (Lienemann et al., 1997; Zwolsmann and van Eck 1999; Dong et al., 2000). On the contrary, in anaerobic conditions, active sulphide co-precipitation rapidly removes $\mathrm{Co}, \mathrm{Cu}, \mathrm{Ni}, \mathrm{Pb}, \mathrm{Zn}$ from the dissolved phase (Balistrieri et al., 1994; Clark et al., 1998; Schlieker et al., 2001). In sediments from the oxic layers of the mature and senescent mangroves, both increasing and stable concentrations were recorded, depending on the metals. These layers, opposite to those of the young swamps, were characterized by the intense reoxidation of sulphides as reflected by very low $\mathrm{pH}$. This re-oxidation probably led to heavy metals being released in the dissolved phase (and loss of inherited carbonate). Depending on the kinetics of reactions, some heavy metals increased in these layers $(\mathrm{Cu}, \mathrm{Zn})$, probably because they were rapidly re-precipitated with iron oxi-hydroxides (Fig. 5 e, f, g). At the same time, the solid concentrations of the other metals $(\mathrm{Cr}, \mathrm{Co})$ decreased because they were probably released from sulphides and not reprecipitated (Fig. 5 e, g). The rapid chemical changes may induce really high metal concentrations in the solid phase as observed in Australia (Clark et al., 1998). Accordingly, the highest HgT concentrations, close to $2 \mathrm{nmol} \mathrm{g}^{-1}$ dry wt, were found in the young mangroves, at the maximum of Eh values.

Clays have high specific surface area and can directly trap heavy metals, but they also may act as a substrate for OM flocculation (Keil et al., 1994) that in turn adsorbs metals. Roulet et al. (2000), found an excellent relationship between $\mathrm{Hg}$ and aluminosilicates. Thus, the chemical and mineralogical compositions of the substrate can influence concentrations and distributions of metals and may explain differences in concentrations with depth or between sites. However, $98 \%$ of mangrove sediments in French Guiana originally come from the Amazon River and are mainly composed of illite, chlorite, kaolinite and smectite (Para and Pujos, 1998), and thus whatever the location of the sediment studied, the mineralogical composition remains essentially the same. Carbonate binding cannot be totally ruled out since the sediment may contain authigenic carbonates in the basal anaerobic layer, inherited from the unvegetated sediments (Zhu et al., 2002).

Taking into account its high specific surface area, organic matter (OM) can form complexes with heavy metal and consequently influence their distributions. Along the mangrove fringe coast of French 
Guiana, the total organic carbon (TOC) in sediments ranged from 0.7 to $20 \%$ depending on the evolution of the forest considered (Marchand et al., 2003). However, no correlation was found between bulk OM and heavy metals concentrations except for mercury $\left(r^{2}=0.77\right)$ (Fig. 7). Many studies have highlighted that the binding of Hg with organic colloïds is significant (Cossa et al., 1996; Stordal et al. 1996; Mounier et al., 2001) and that OC concentrations can influence Hg cycling. The higher concentrations in $\mathrm{Hg}$ in mangrove than in unvegetated sediments result from some "hot spot", which origin were not evidenced, and the fact that mangrove sediments were richer in OM than the shoreface sediment. Specific sources of heavy metals are very difficult to identify. However, concerning Hg pollution, recent studies (Roulet et al., 1996, 2000) highlighted the role played by the erosion of Amazonian soils that are originally rich in mercury, and the influence of run-off from gold mining activities.

\section{Accumulation of heavy metals in mangrove plants.}

Mangrove plants require certain heavy metals as essential nutrients; however an excess in these nutrients may potentially have adverse, ecotoxicological consequences for mangrove communities. Each mangrove plant species has specific adaptation systems, which may control their behavior towards heavy metals. To cope with high salinity, Avicennia can exclude salt from leaves through glandular excretion; this system can also eliminate excess metals (MacFarlane and Burchett, 1999). Mangrove roots may act as a barrier for metal translocation: higher concentrations were found in roots compared to the aerial parts in many mangrove plants (Tam and Wong, 1997; MacFarlane and Burchett, 2002). Tam and Wong (1997) also suggested that the role of mangroves in retaining metals depend on the ages of plants and on their biomass production. In French Guiana, we have examined heavy metals content of 5 mangrove species. The average concentrations are given in Tab. 3. $\mathrm{Cr}, \mathrm{Cu}$, Co, Ni ranged between 42 and 509, 0 and 207, 7 and 41, 3 and $108 \mathrm{nmol} \mathrm{g}^{-1}$ respectively. $\mathrm{Pb}$ concentrations were below the detection limit in all mangrove plant species. No specific differences in concentrations were found between leaves and stem. Results do not show any specific correlation with the heavy metal content of the sediment, as have been previously reported. Even at high concentrations in sediments, heavy metals may or may not be available for plants. DOC in soils, forming soluble 
organic metallic complexes, has been suggested to increase the availability of metal to plants (Antoniadis and Alloway, 2002; Hamon et al., 1995), whereas the precipitation of metal sulphides under anoxic conditions lowers the availability (Lacerda, 1998). Low mercury concentrations were found in all plants except in Rhizophora leaves, for which concentration occasionally reached more than $0.54 \mathrm{nmol} \mathrm{g}^{-1}$. This high concentration is more likely to have an atmospheric origin than to be the result of an uptake by plant roots followed by translocation and accumulation in the leaves of the plants. At this time, the concentrations in the sediment beneath Rhizophora stands were low, close to $0.25 \mathrm{nmol} \mathrm{g}^{-1}$ dry wt. The biological effects that heavy metals might cause are difficult to assess. However, on the island of Trinidad, a mutation in a local population of Rhizophora was reported in coincidence with elevated mercury levels in the underlying sediment (Klekowski et al., 1999).

Crenea maritima, which is an angiosperm dicotyledon, appeared to be the most contaminated mangrove plant, with concentrations up to $1988 \mathrm{nmol} \mathrm{g}^{-1}$ of $\mathrm{Zn}$. These small shrubs develop on the seashore of the mangrove swamps and are totally submerged, leaf and stem included, at high tide, possibly explaining the high heavy metals concentrations found both in leaves and hardwood. The fern Acrostichum aureum, had the lowest heavy metal concentrations although it developed on the same substrate as the other plants. These results highlight how variable the metal bio-accumulation behaviors of mangrove communities are with respect to the heavy metal content of their sedimentary substrate.

\section{Conclusions}

Accumulation of heavy metal in mangrove sediments collected in French Guiana appeared to be moderate. Since no differences were evident between samples collected in swamps located upstream and downstream of urban areas, we propose that the metal content originated largely further upstream of the mangrove swamps studied. The origin of the sediment is from the Amazon watershed and it has been transported northwestward through the movement of mudbanks, a movement which is the result of the continuous alternation of accumulation and transport phases. 
Variations of metal concentrations with depth or between mangroves appear to result from diagenetic processes rather than from anthropogenic inputs. Iron and manganese cycling were strongly correlated with redox conditions, which in turn depended on mangrove plant species, seasonal fluctuation of boundary conditions, and quantity and reactivity of organic matter. Fe and Mn concentration resulted from balances between precipitation and mobilization in oxic and anaerobic layers. In anaerobic conditions, sulphate reduction processes mediated by bacteria, induced sulphur precipitation. Reduced Fe was frequently associated with sulphur and precipitated as pyrite. The high content of solid phase $\mathrm{Mn}$ at depth probably reflects inherited carbonate from shoreface sediments, the carbonate content being dissolved in the upper oxic, acidic layer. During dry seasons, the older parts of the swamps were characterized by a zone of sulphide oxidation overlying a zone of sulphate reduction. Sulphide oxidation probably induced metal release in the dissolved phase, and carbonate dissolution. Metals could then be subsequently co-precipitated as oxi-hydroxides. Two sites of higher metal concentrations in the solid phase were found, one at the maximum of sulphate-reduction and the second at the higher redox values. Lower concentrations of metals were found in the sulphide oxidation zone of the senescent mangrove. Although the organic content may have a strong influence on metal cycling, a good correlation was found only with $\mathrm{HgT}$ (except at highest values). Crenea maritima was the mangrove plant species with highest metal accumulation, probably because this small shrub was totally covered at high tides. The fern Acrostichum aureum was the less contaminated, probably because it thrives in rear mangroves and is less frequently submerged by flood-tide waters.

This preliminary study concerning heavy metal distribution along the mangrove fringed coast of French Guiana highlighted some points that have to be confirmed in a future research effort. Oxidized mineral species have to be searched for in the young Avicennia mangrove swamps, whereas sulphide species have to be searched for in the old swamps during the rainy season. The study of the relationships between $\mathrm{Hg}$ and $\mathrm{OM}$ has to be developed, and the methylated forms of $\mathrm{Hg}$ searched for, mainly in the older swamps since $\mathrm{HgS}$ may serve as substrate for methylation. Finally, denitrification process should be studied since this process can occur before Fe, Mn, S reduction. 


\section{Acknowledgements}

This research was supported by INSU and the PNEC Guyane. The authors would like to thank IRD Cayenne, ENGREF Kourou and F. Fromard (Univ. P. Sabatier, Toulouse, France) for their valuable assistance in the field. We would also like to thank R. Boscardin (ISTO, Orléans, France) for technical assistance The help of R.C. Aller (Stony Brook University, USA) for the improvement of this manuscript is gratefully acknowledged. 


\section{References}

Albéric, P., Sarazin, G., Michard, G., 1996. Combined amino acid speciation in lake sediment and porewater (Aydat lake, France). Aq. Geochem. 2: 29-49.

Aller, R.C. 1998. Mobile deltaic and continental shelf muds as suboxic, fluidized bed reactors. Mar. Chem. 61: 143-155.

Aller, R.C., Heilbrun, C., Panzeca, C., Zhu, Z., Baltzer, F., 2004. Coupling between sedimentary dynamics, early diagenetic processes, and biogeochemical cycling in the Amazon-Guianas mobile mud belt: coastal French Guiana. Mar. Geol. 208: 331-360.

Allison, M.A., Lee, M.T, Ogston, A.S., Aller, R.C., 2000. Origin of Amazon mudbanks along the northeastern coast of South America. Mar. Geol. 163: 241-256.

Antoniadis, V. and Alloway, B.J., 2002. The role of dissolved organic carbon in the mobility of Cd, Ni and $\mathrm{Zn}$ in sewage sludged-amanded soils. Environ. Pollut. 117: 515-521.

Aragon, G. and Miguens, F., 2001. Microscopic analysis of pyrite in the sediments of two Brazilian mangrove ecosystems. Geo-Mar. Letters 21: 157-161.

Balistrieri, L.S., Murray, J.W., Paul, B., 1994. The geochemical cycling of trace elements in a biogenic meromictic lake. Geochim. Cosmochim. Acta 58: 3993-4008.

Boulègue, J., Lord, C.J., III, Church, T.M., 1982. Sulfur speciation and associated trace metals (Fe, $\mathrm{Cu})$ in the porewaters of Great Marsh, Delaware. Geochim. Cosmochim. Acta 46: 453-464.

Chin, Y.-P., Gschwend, P.M., 1991. The abundance, distribution, and configuration of porewater organic colloids in recent sediments. Geochim. Cosmochim. Acta 55: 1309-1317.

Clark, M.W., McConchie, D., Lewis, D.W., Saenger, P., 1998. Redox stratification and heavy metal partitioning in Avicennia-dominated mangrove sediments: a geochemical model. Chem. Geol. 149: $147-171$.

Cossa, D., Coquery, M., Gobeil, C., Martin, J.M., 1996. Mercury fluxes at the ocean margins. In: Regional and Global cycle of mercury: sources, fluxes, and mass balances. Baeyens, W., Ebinghaus, R. and Vasiliev, O. (eds) Kluwer Academics Publishers, Netherlands, pp 229-247. 
Cossa, D., Coquery, M., Nakhlé, K., Caisse, D. 2002. Dosage du mercure total et du monométhylmercure dans les organismes et les sédiments marins. Méthodes d'analyses en milieu marin, IFREMER publishing, France. 28pp. ISBN 2-84433-105-X.

Dong, D., Nelson, Y.M., Lion, L.W., Shuler, M.L., Ghiorse, W.C., 2000. Adsorption of Pb and Cd onto metal oxides and organic material in natural surface coatings as determined by selective extractions: new evidence for the importance of Mn and Fe oxides. Water Research 34: 427-436.

Fromard, F., Puig, H., Mougin, E., Marty, G., Betoulle, J.L., Cadamuro, L., 1998. Structure, above ground biomass and dynamics of mangrove ecosystems: New data from French Guiana . Oecologia 115: 39-53.

Gaillardet, J., Dupre, B., Allègre, C.J., Négrel, P., 1997. Chemical and physical denudation in The Amazon River Basin. Chem. Geol. 142: 141-173.

Giani, L., Bashan, Y., Holguin, G., Strangmann, A., 1996. Characteristics and methanogenesis of the Balandra lagoon mangrove soils, Baja California Sur, Mexico. Geoderma 72: 149-160.

Gribsholt, B., Kristensen, E., 2002. Impact of sampling methods on sulphate reducing rates and dissolved organic carbon (DOC) concentrations in vegetated salt marsh sediments. Wetlands Ecology and Management 10: 371-379.

Guo, T., DeLaune, R.D., Patrick, Jr., W.H., 1997. The influence of sediment redox chemistry on chemically active forms of arsenic, cadmium, chromium, and zinc in estuarine sediment. Environ. Internat. 23: 305-316.

Hamon, R.E., Lorenz, S.E., Holm, P.E., Christensen, T.H., McGrath, S.P., 1995. Changes in trace metals species and other components of the rizosphere during growth of radish. Plant and Environment 18: 749-756.

Harbison, P., 1986. Mangrove muds: a sink and a source for trace metals Mar. Pollut. Bull. 17: 246250.

Huc, A.Y., 1980. Origin and formation of organic matter in recent sediments and its relation to kerogen. In: Kerogen: Matière organique insoluble des roches sédimentaires, B. Durand. Technip. (ed.), Paris, pp. 446-474. 
Huerta-Diaz, M.A., Morse, J.W., 1992. Pyritization of trace metals in anoxic marine sediments.

Geochim. Cosmochim. Acta 56: 2681-2702.

Keil, R.G., Montlucon, D.B., Prahl, F.R., Hedges, J.I., 1994. Sorptive preservation of labile organic matter in marine sediments. Nature 370: 549-552.

Klekowski, E.J., Temple, S.A., Siung-Chang, A.M., Kumarsingh, K.K., 1999. An association of mangrove mutation, scarlet ibis, and mercury contamination in Trinidad, West Indies. Environ. Pollut.105: 185-189.

Lacerda, L.D., Martinelli, L.A., Rezende, C.A., Mozetto, A.A., Ovalle, A.R.C., Victoria, R.I., Silva, C.A.R., Nogeuira, F.B., 1988. The fate of heavy metals in suspended matter in a mangrove creek during a tidal cycle. Sci. Tot. Environ. 75: 249-259.

Lacerda, L.D., 1998. Biogeochemistry of trace metals and diffuse pollution in mangrove ecosystem. International Society of Mangrove Ecosystem, Okinawa.

Lacerda, L.D., Ribeiro, M.G., Guiros, B.B., 1999. Manganese dynamics in a mangrove, mud flat tidal creek in SE Brazil. Mangrove and Salt Marshes 3: 105-115

Lienemann, C.-P., Taillefert, M., Perret, D., Gaillard, J.-F., 1997. Association of cobalt and manganese in aquatic systems: Chemical and microscopic evidence. Geochim. Cosmochim. Acta 61: 1437-1446. Machado, W, Moscatelli, M, Rezende, L.G., Lacerda, L.D., 2002 a. Mercury, zinc, copper accumulation in mangrove sediments surrounding a large landfill in southeast Brazil. Environ. Pollut. 120: $455-461$.

Machado, W., Silva-Filho, E.V., Oliveira, R.R., Lacerda, L.D., 2002 b. Trace metal retention in mangrove ecosystems in Guanabra Bay, SE Brazil. Mar. Pollut. Bull. 44: 1277-1280.

MacFarlane, G.R., Burchett, M.D., 1999. Zinc distribution and excretion in the leaves of the grey mangrove, Avicennia marina (Forsk.) Vierh. Environ. Exp. Bot. 41: 167-175.

MacFarlane, G.R., Burchett, M.D., 2002. Toxicity, growth and accumulation relationships of copper, lead and zinc in the grey mangrove Avicennia marina (Forsk.) Vierh. Mar. Environ. Res. 54: 65-84. Mackey, A.P., Hodgkinson, M.C., 1995. Concentration and spatial distribution of trace metals in mangrove sediments from the Brisbane River, Australia. Environ. Pollut. 90: 181-186. 
Marchand, C., Lallier-Vergès, E., Baltzer, F., 2003. The composition of sedimentary organic matter in relation to the dynamic features of a mangrove-fringed coast in French Guiana. Estuar. Coastal Shelf Sci. 56: 119-130.

Marchand, C., Baltzer, F., Lallier-Vergès, E., Albéric P., 2004. Interstitial water chemistry in mangrove sediments in relationship to species composition and developmental stage. (French Guiana). Mar. Geol. 208: 361-381.

Mason, R.P., Fitzgerald, W.F., Morel, F.F.M., 1994. The biogeochemical cycling of elemental mercury: anthropogenic influences. Geochim. Cosmochim. Acta 58: 3191-3198.

Mortimer, R.J.G. and Rae, J.E., 2000. Metal speciation $(\mathrm{Cu}, \mathrm{Zn}, \mathrm{Pb}, \mathrm{Cd})$ and organic matter in oxic to suboxic salt marsh sediments, Severn Estuary, Soutwest Britain. Mar. Pollut. Bull. 40: 377-386.

Mounier, S., Lacerda, L.D., Marins, R.V., Bemaim, J., 2001. Copper and mercury complexing capacity of organic matter from a mangrove mud flat environment, Sepetiba bay, Brazil.

Environmental Contamination and Toxicology 67: 519-525.

Nissenbaum, A., Swaine, D.J., 1976. Organic-metal interactions in recent sediments: the role of humic substances. Geochim. Cosmochim. Acta 40: 809-816.

Parra, M. and Pujos, M., 1998. Origin of late Holocene fine-grained sediments on the French Guiana shelf. Cont. Shelf Res. 18: 1613-1629.

Quémerais, B., Cossa, D., Rondeau, B., Pham, T.T., Fortin, B., 1998. Mercury distribution in relation to iron and manganese in the water of the St. Laurent River. Sci. Tot. Environ. 213: 193-201.

Roulet, M., Lucotte, M., Rheault, I., Tran, S., Farella, N., Canuel, R., Mergler, D., Amorim, M. 1996. Mercury in Amazonian soils: accumulation and release. In: Proceedings of the $4^{\text {th }}$ International Symposium on the Geochemistry of the Earth Surface, 22-28 July, Ilkey, UK, pp. 453-457.

Roulet, M., Lucotte, M., Canuel, R., Farella, N., Courcelles, M., Guimaraes, J.R.D., Mergler D., Amorin, M., 2000. Increase in Mercury contamination recorded in lacustrine sediments following deforestation in the central Amazon. Chem. Geol. 165: 243-266.

Schlieker, M., Schüring, J., Hencke, J., Shulz, H.D., 2001. The influence of redox processes on trace element mobility in a sandy aquifer_an experimental approach. J. Geochem. Explor. 73: 167-179. 
Scholander, P.F., Van dam, L., Scholander, S. I., 1955. Gas exchange in the roots of mangrove. Amer. J. Bot. 42: 92-98.

Silva, C.A.R, Lacerda, L.D., Ovalle, A.R., Rezende, C.E., 1998. The dynamics of heavy metals trough litterfall and decomposition in a red mangrove forest. Mangrove and Salt Marshes 2: 149-157. Stordal, M.C., Gill, G.A., Wen, L.S., Santchi, P.H., 1996. Mercury phase speciation in surface water of three Texas estuaries: Importance of colloïdal forms. Limnol. Oceanogr. 41: 52-61.

Tam, N.F.Y., Wong, Y.S., 1995. Spatial and temporal variations of heavy metal contamination in sediments of a mangrove swamp in Hong Kong Mar. Pol. Bull. 31: 254-261.

Tam, N.F.Y., Wong, Y.S., 1997. Accumulation and distribution of heavy metals in a simulated mangrove system treated with sewage. Hydrobiologia 352: 67-75.

Tam, N.F.Y., Wong, Y.S., 2000. Spatial variation of heavy metal in surface sediments of Hong Kong mangrove swamps. Env. Pollut. 110: 195-205.

Zhu, Z., Aller, R.C., Mack, J., 2002. Stable carbon isotope cycling in mobile coastal muds of Amapa, Brazil. Continental Shelf Research 22: 2065-2079.

Zwolsman, J.J.G., van Eck, G.T.M., 1999. Geochemistry of major elements and trace metals in suspended matter of the Scheldt estuary, southwest Netherlands. Mar. Chem. 66: 91-111. 


\section{Figures captions:}

Fig. 1: Map of the studied area showing the location of cores (adapted from Fromard et al., 1998)

Fig. 2: Depth distribution of various parameters from sediment cores collected in young $A$. germinans mangrove (S1) (low sedimentary organic content, flooded at each tide) in Sinnamary at the end of the rainy season, a: total organic carbon (TOC)content $(\%), \mathrm{b}$ : Eh $(\mathrm{mV})$ and $\mathrm{pH}$ values, $\mathrm{c}$ : dissolved iron $\left(\mu \mathrm{mol} \mathrm{l}^{-1}\right)$ and total solid sulphur $\left(\mu \mathrm{mol} \mathrm{g}{ }^{-1}\right), \mathrm{d}$ : dissolved manganese $\left(\mu \mathrm{mol} \mathrm{l}^{-1}\right)$ and total solid manganese $\left(\mu \mathrm{mol} \mathrm{g}^{-1}\right)$, e: total nickel and lead $\left(\mu \mu \mathrm{mol} \mathrm{g}{ }^{-1}\right), \mathrm{f}$ : total solid iron $\left(\mu \mathrm{mol} \mathrm{g}{ }^{-1}\right)$ and total mercury $\left(\mathrm{nmol} \mathrm{g}{ }^{-1}\right), \mathrm{g}$ : total solid zinc and chromium $\left(\mu \mathrm{mol} \mathrm{g}^{-}\right.$ $\left.{ }^{1}\right)$.

Fig. 3: Depth distribution of various parameters from sediment cores collected in "recolonized cemetery" $A$. germinans mangrove (S2) (low sedimentary organic content, flooded at each tide, buried roots) in Sinnamary at the end of the rainy season, a: total organic carbon (TOC)content $(\%), \mathrm{b}$ : Eh (mV) and pH values, c: dissolved iron $\left(\mu \mathrm{mol} \mathrm{l^{-1 }}\right)$ and total solid sulphur $\left(\mu \mathrm{mol} \mathrm{g}{ }^{-1}\right)$, d: dissolved manganese $\left(\mu \mathrm{mol} \mathrm{l}^{-1}\right)$ and total solid manganese $\left(\mu \mathrm{mol} \mathrm{g}{ }^{-1}\right)$, e: total solid copper, cobalt, nickel and lead $\left(\mu \mu \mathrm{mol} \mathrm{g} \mathrm{g}^{-1}\right), \mathrm{f}$ : total solid iron $\left(\mu \mathrm{mol} \mathrm{g}^{-1}\right)$ and total mercury (nmol g $\left.{ }^{-1}\right)$, g: total solid zinc and chromium $\left(\mu \mathrm{mol} \mathrm{g} \mathrm{g}^{-1}\right)$.

Fig. 4: Depth distribution of various parameters from sediment cores collected in senescent $A$. germinans mangrove (S3) (high sedimentary organic content, flooded only at spring tide) in Sinnamary at the end of the rainy season, a: total organic carbon (TOC)content $(\%), \mathrm{b}$ : Eh $(\mathrm{mV})$ and $\mathrm{pH}$ values, c: dissolved iron $\left(\mu \mathrm{mol} \mathrm{l}^{-1}\right)$ and total solid sulphur $\left(\mu \mathrm{mol} \mathrm{g}{ }^{-1}\right), \mathrm{d}$ : dissolved manganese $\left(\mu \mathrm{mol} \mathrm{l} \mathrm{l}^{-1}\right)$ and total solid manganese $\left(\mu \mathrm{mol} \mathrm{g} \mathrm{g}^{-1}\right)$, e: total solid copper, cobalt, nickel and lead $\left(\mu \mu \mathrm{mol} \mathrm{g} \mathrm{g}^{-1}\right)$, f: total solid iron $\left(\mu \mathrm{mol} \mathrm{g}{ }^{-1}\right)$ and total mercury $\left(\mathrm{nmol} \mathrm{g}^{-1}\right)$, $\mathrm{g}$ : total solid zinc and chromium $\left(\mu \mathrm{mol} \mathrm{g} \mathrm{g}^{-1}\right)$

Fig. 5: Depth distribution of various parameters from sediment cores collected in mature $A$. germinans mangrove (S4) (high sedimentary organic content, flooded only at spring tide) in Sinnamary at the beginning of the rainy season, a: total organic carbon (TOC)content $(\%), \mathrm{b}$ : Eh $(\mathrm{mV})$ and $\mathrm{pH}$ values, $\mathrm{c}$ : dissolved iron $\left(\mu \mathrm{mol} \mathrm{l}^{-1}\right)$ and total solid sulphur $\left(\mu \mathrm{mol} \mathrm{g}{ }^{-1}\right), \mathrm{d}$ : dissolved manganese $\left(\mu \mathrm{mol} \mathrm{l}^{-1}\right)$ and total solid manganese $\left(\mu \mathrm{mol} \mathrm{g} \mathrm{g}^{-1}\right)$, e: total solid copper, cobalt, nickel and lead $\left(\mu \mu \mathrm{mol} \mathrm{g}{ }^{-1}\right), \mathrm{f}:$ total solid iron $\left(\mu \mathrm{mol} \mathrm{g}{ }^{-1}\right)$ and total mercury $\left(\mathrm{nmol} \mathrm{g}^{-1}\right), \mathrm{g}^{\text {: }}$ total solid zinc and chromium $\left(\mu \mathrm{mol} \mathrm{g}{ }^{-1}\right)$.

Fig. 6: Schematic diagram of Fe, Mn, S, Corg geochemistry in an Avicennia mangrove swamp, with respect to forest development and season.

Fig. 7: Total solid mercury concentrations versus total organic carbon measured on sediment cores from Kaw and Sinnamary (all values including except those from hot spot, $\mathrm{S} 3$ core : $50 \mathrm{~cm}$ and $\mathrm{S} 1$ core) 


\section{Table list}

Table 1: Comparisons of our measurements with the certified values. Detection limits are expressed as three times the standard deviation determined from numerous analyses of blanks. HgT comparisons from Cossa et al. 2002.

Table 2: Concentrations of heavy metals in shoreface sediment and cores collected in Sinnamary and Kaw mangroves. Average, standard deviation (SD), maximum and minimum values.

* Data from Gaillardet et al., 1997, concentrations in the suspended sediments of the Amazon mainstreams. $\mathrm{a}: \mathrm{n}=3$

Table 3: Concentrations of heavy metals in mangrove plant species $(\mathrm{Pb}$ concentrations were below the detection limit). 
Fig. 1

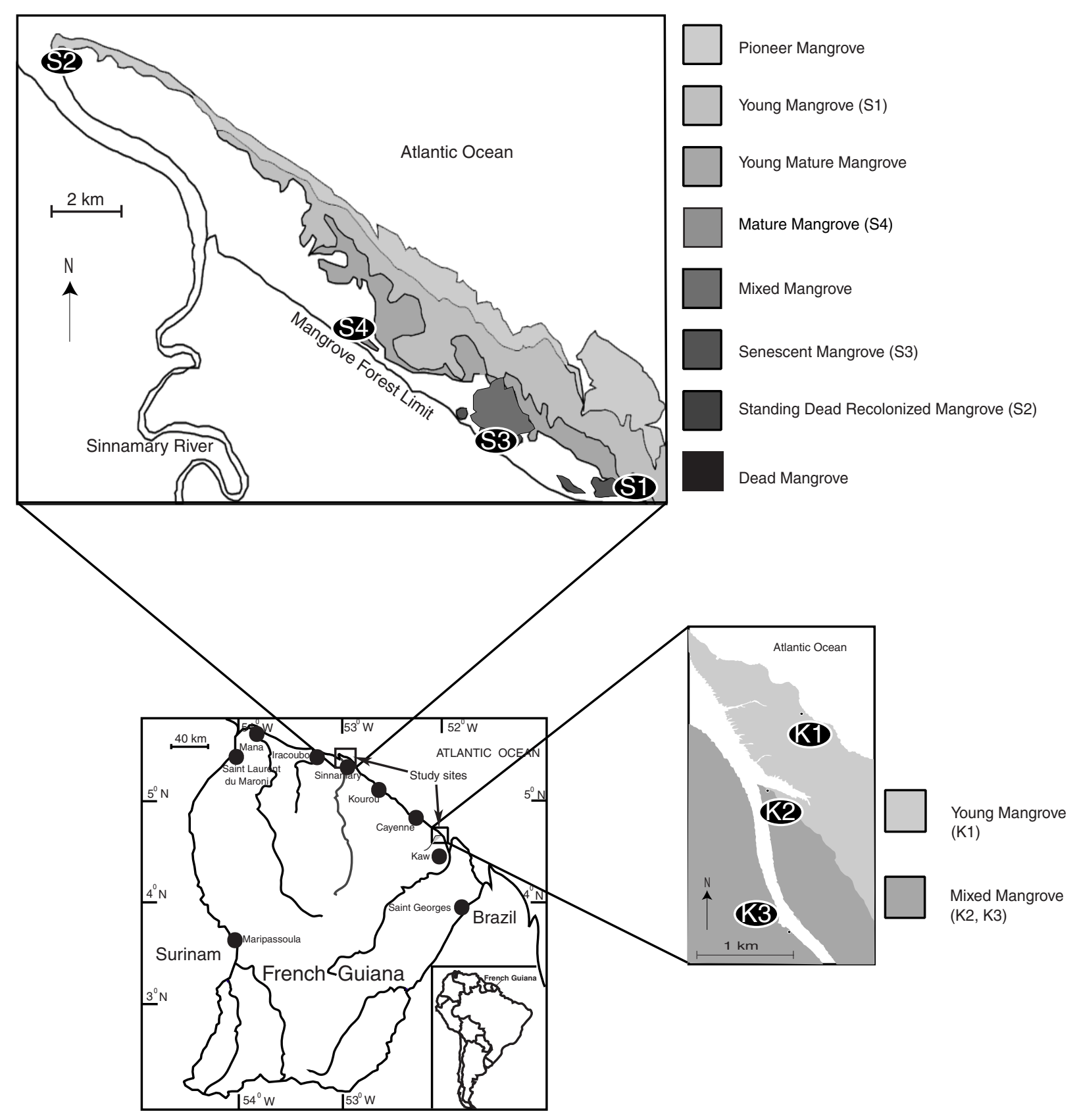


Fig. 2
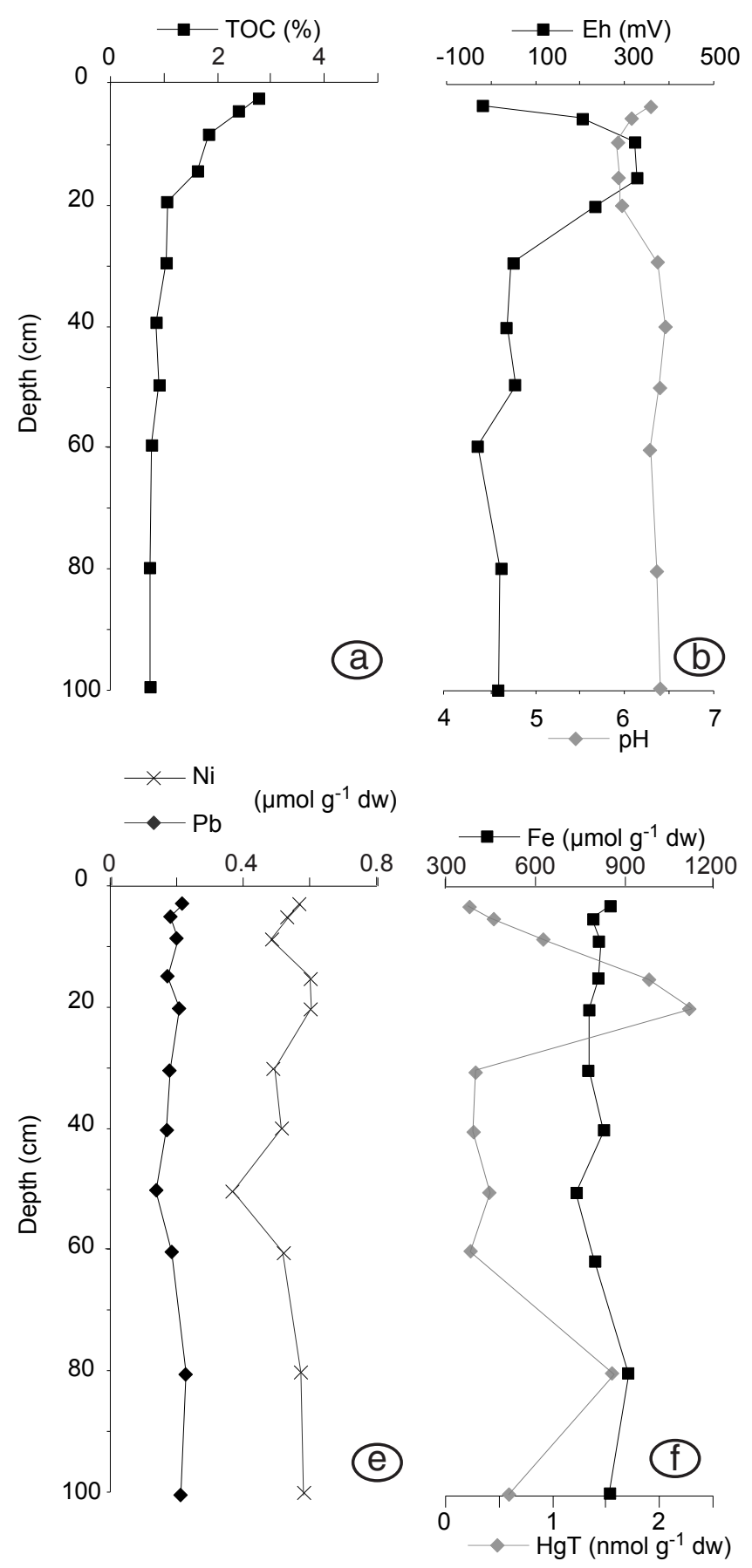
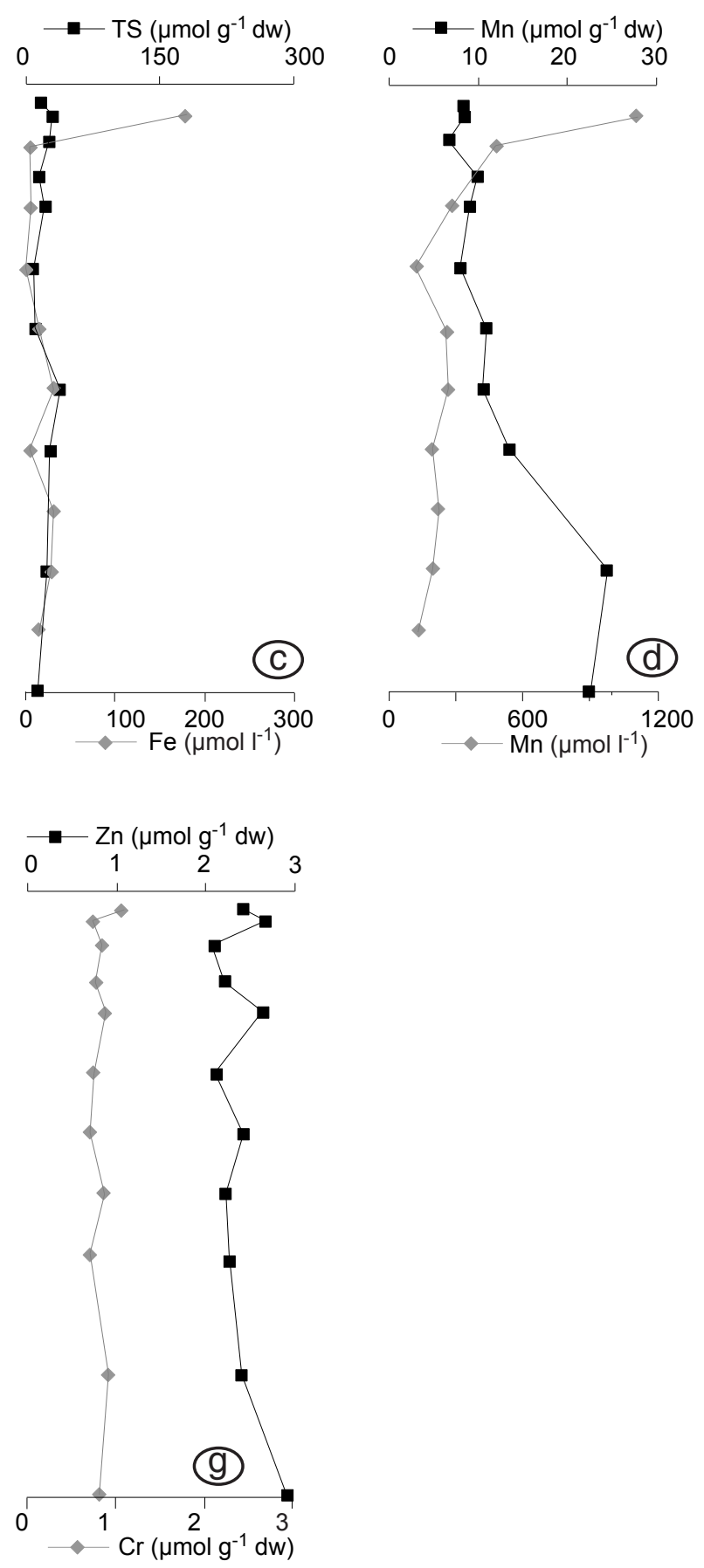
Fig. 3
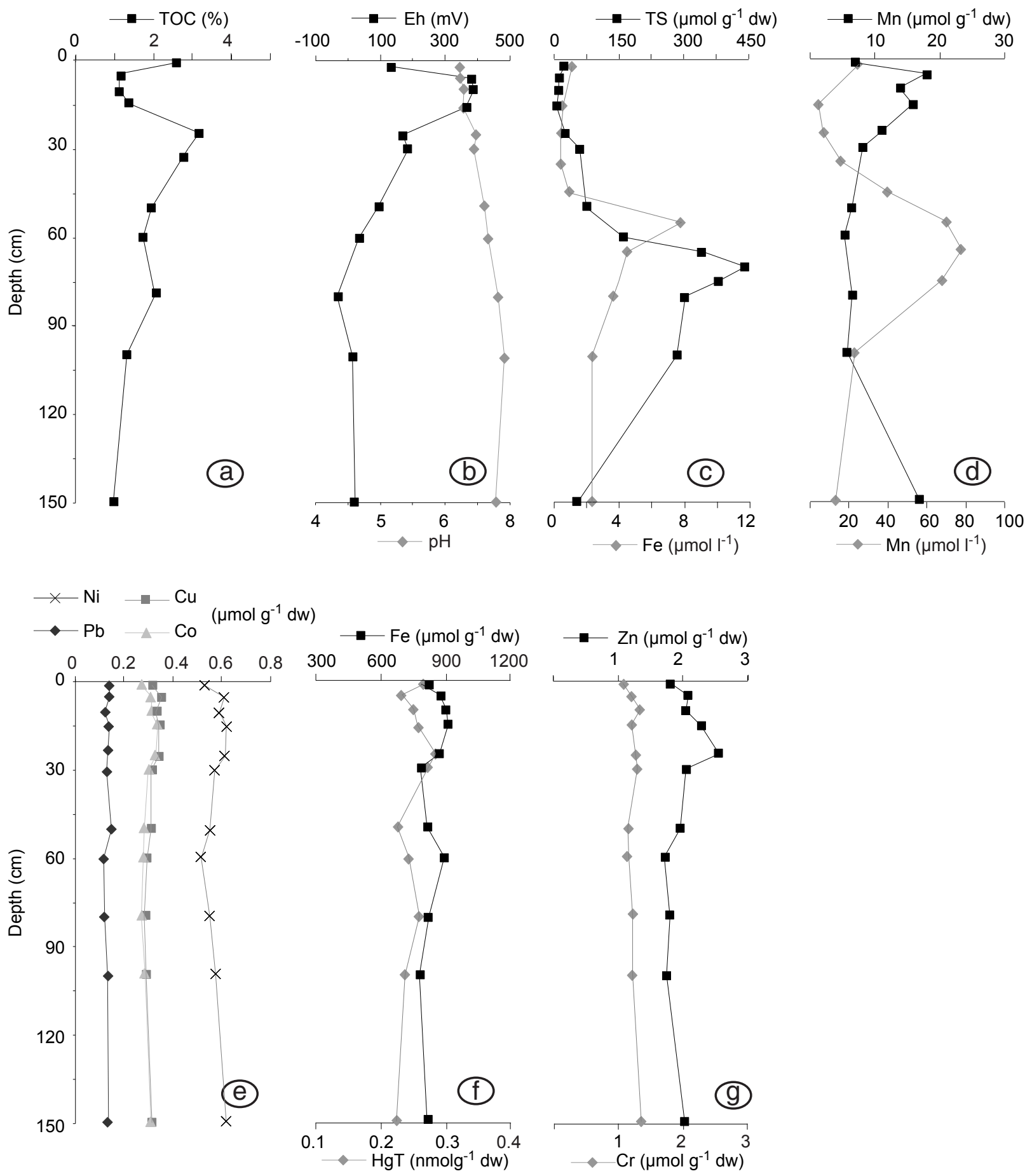
Fig. 4
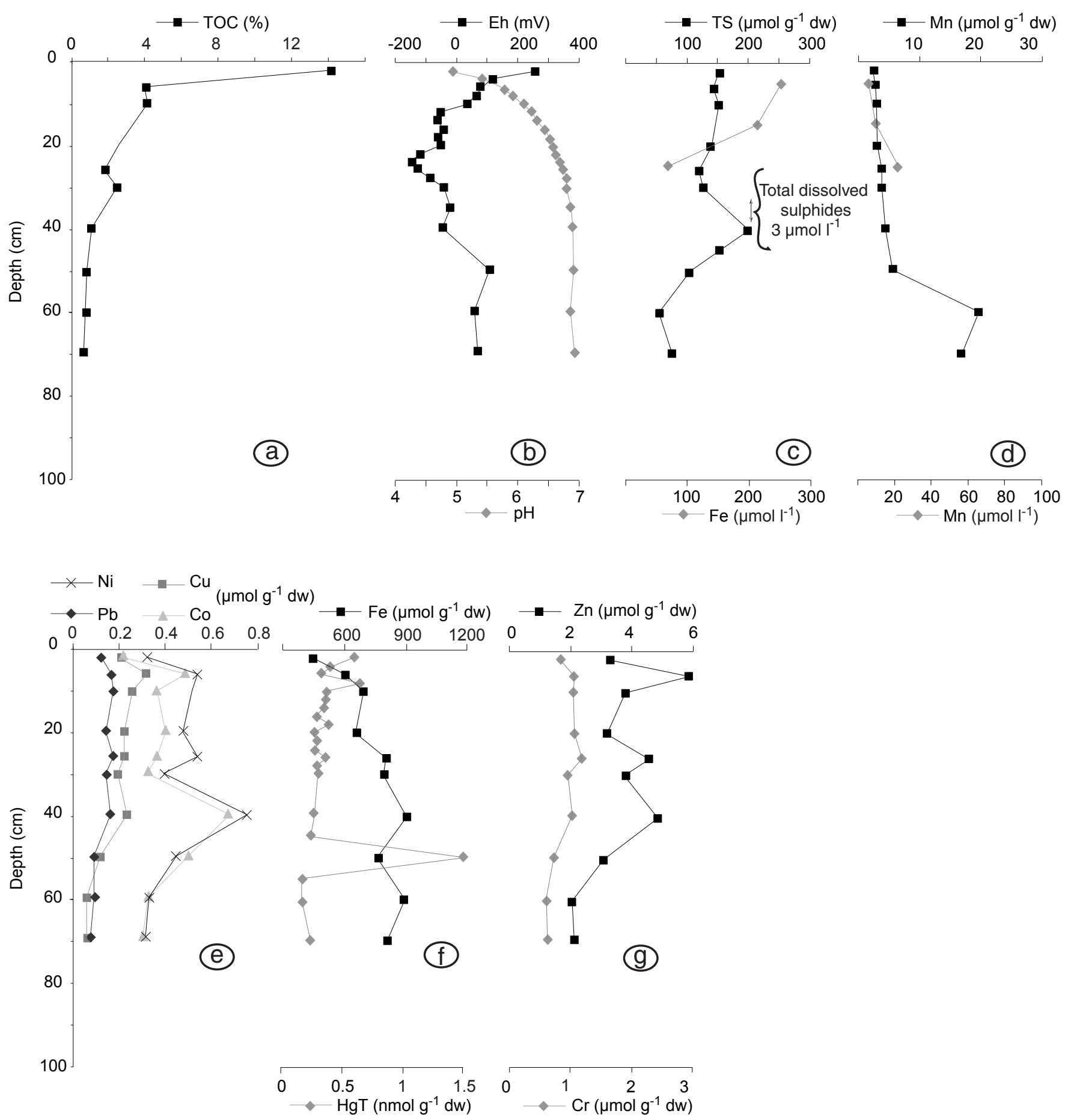
Fig. 5
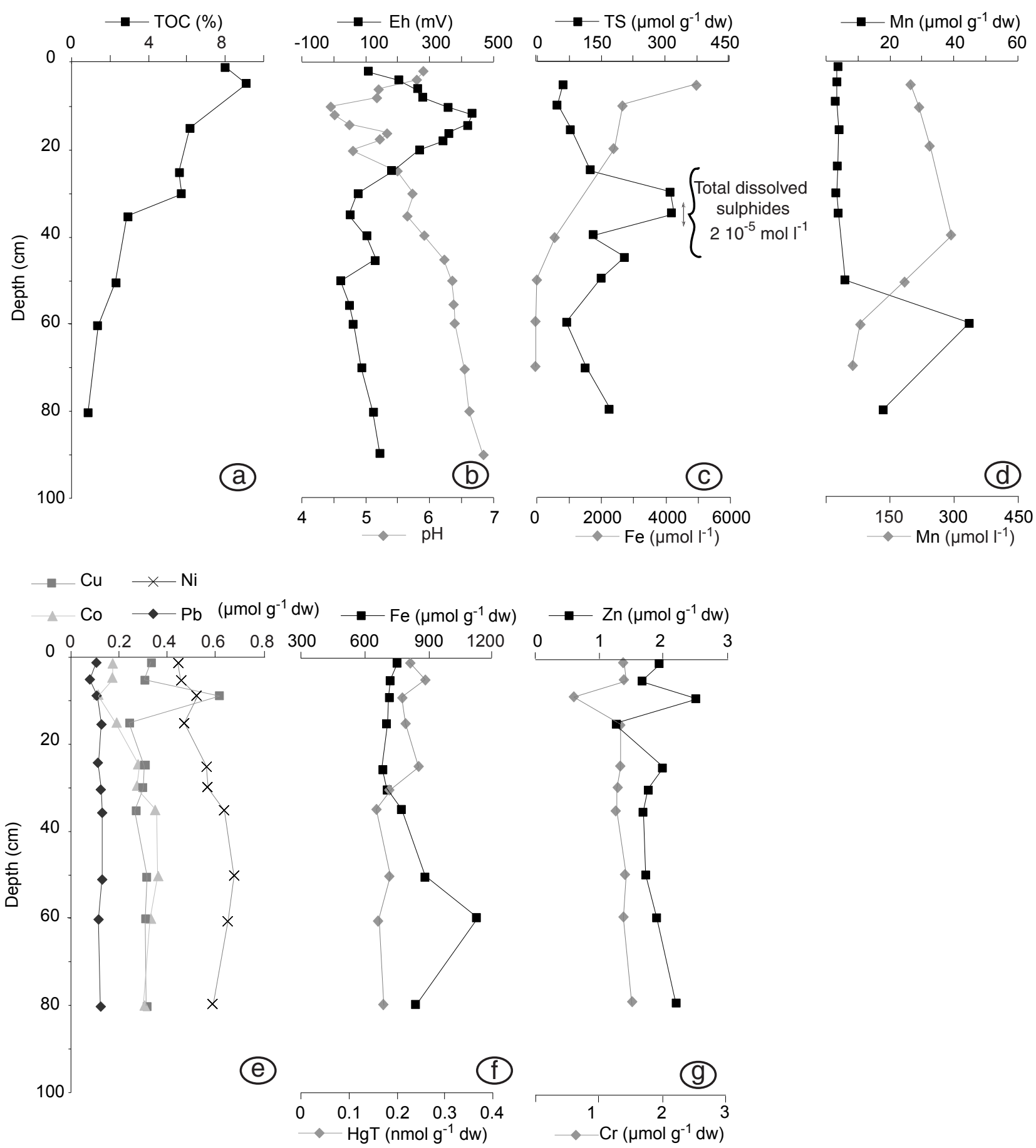


\section{A/ Young Avicennia mangrove swamp}

Flooded at each tide

A1/ Normal

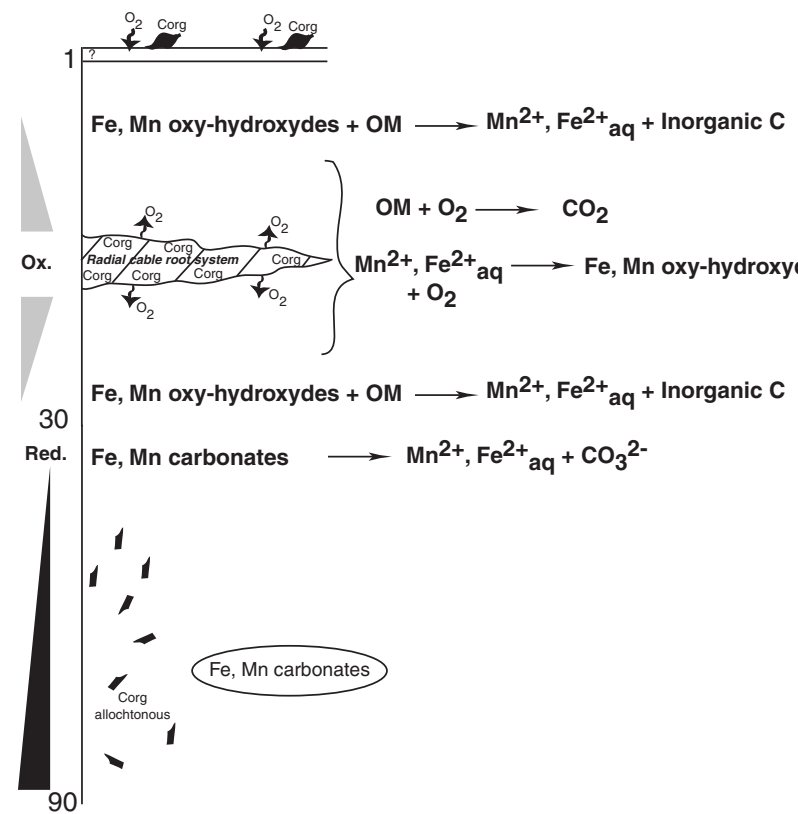

\section{A2/ Recolonized}

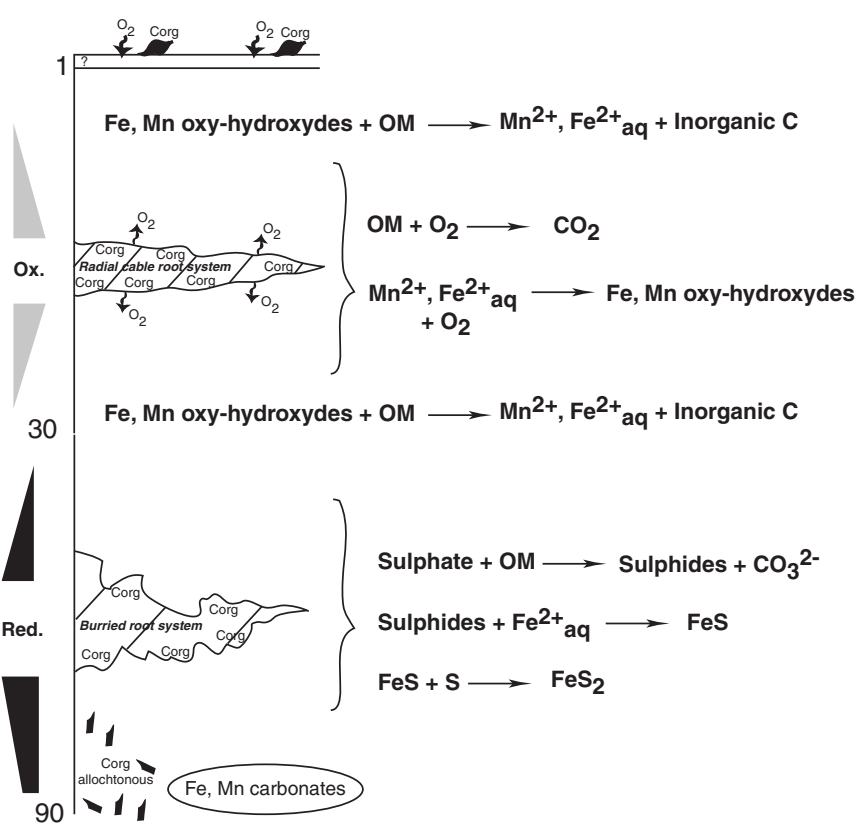

\section{B/ Old Avicennia mangrove swamp}

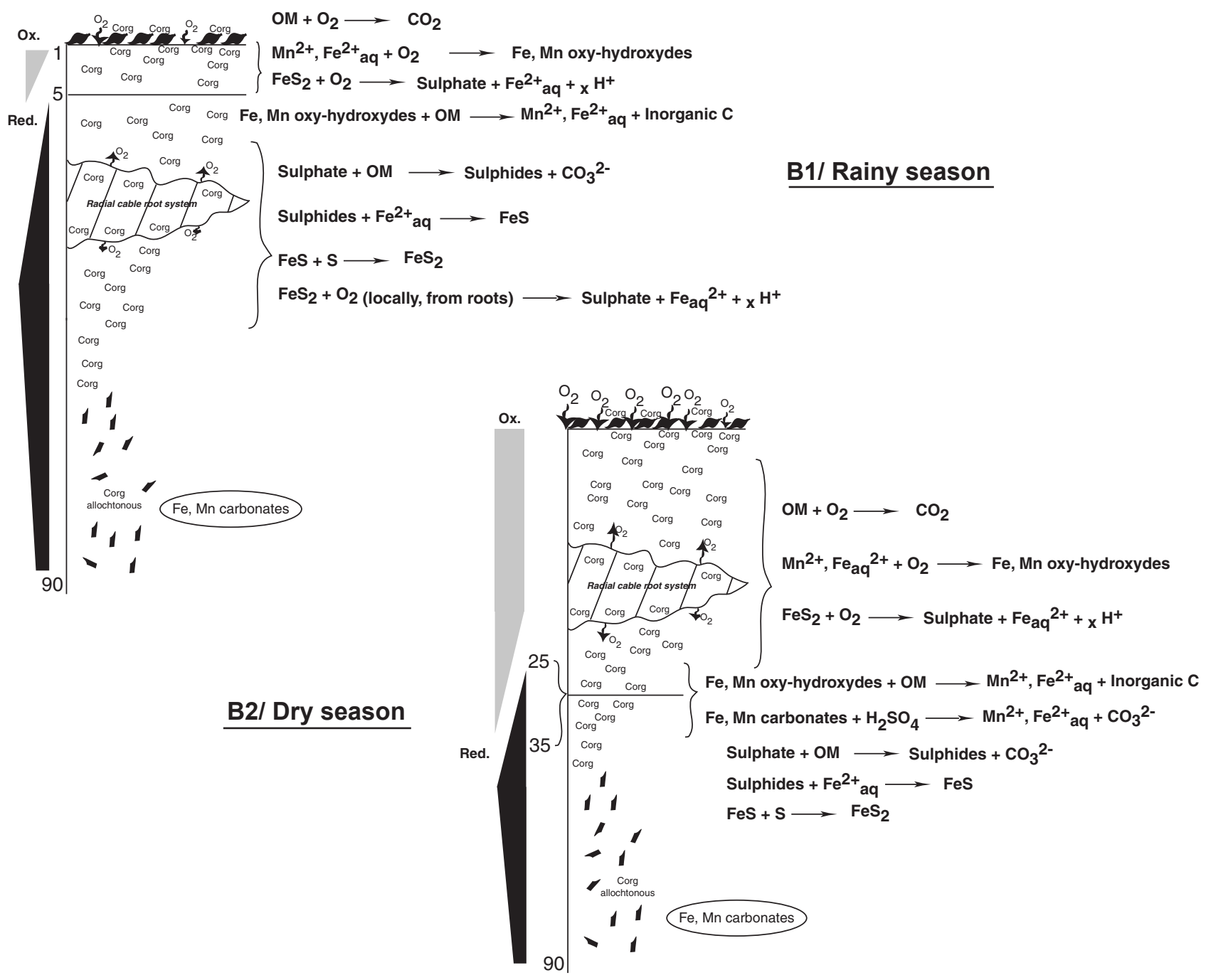

22 A. germinans radial cable root system 
Fig. 7

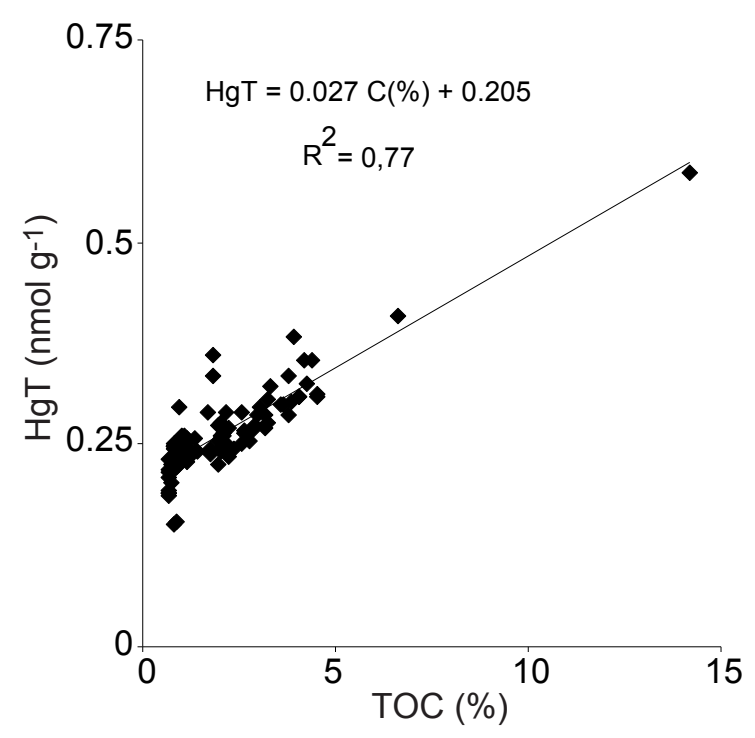




\begin{tabular}{|c|c|c|c|c|c|}
\hline & $\begin{array}{c}\text { HR-ICP-AES } \\
\text { detection limit } \\
\left(\mathrm{nmol} \mathrm{g}{ }^{-1}\right) \\
\end{array}$ & $\begin{array}{c}\text { LGC } 6137 \\
\text { Certified values } \\
\left.(\mathrm{nmol} \mathrm{g})^{-1}\right) \\
\end{array}$ & $\sigma$ & $\begin{array}{c}\text { Measured } \\
\text { concentrations } \\
\left(\mathrm{nmol} \mathrm{g}{ }^{-1}\right)(\mathrm{n}=6) \\
\end{array}$ & $\sigma$ \\
\hline Co & 28 & 232 & 29 & 233 & 24 \\
\hline $\mathrm{Cr}$ & 16 & 904 & 135 & 1182 & 83 \\
\hline $\mathrm{Cu}$ & 28 & 497 & 25 & 525 & 27 \\
\hline $\mathrm{Ni}$ & 27 & 537 & 43 & 689 & 83 \\
\hline $\mathrm{Pb}$ & 29 & 352 & 17 & 385 & 29 \\
\hline \multirow[t]{2}{*}{$\mathrm{Zn}$} & 17 & 3538 & 245 & 3715 & 270 \\
\hline & $\begin{array}{c}\text { AMA } 254 \\
\text { detection limit } \\
\left.(\mathrm{nmol} \mathrm{g})^{-1}\right)\end{array}$ & $\begin{array}{c}\text { MESS-2 } \\
\text { Certified values } \\
\quad\left(\mathrm{nmol} \mathrm{g}^{-1}\right)\end{array}$ & $\sigma$ & $\begin{array}{c}\text { Measured } \\
\text { concentrations } \\
\left(\mathrm{nmol} \mathrm{g}^{-1}\right)(\mathrm{n}=6)\end{array}$ & $\sigma$ \\
\hline $\mathrm{Hg}$ & 0,035 & 0,46 & 0,04 & 0,44 & 0,01 \\
\hline
\end{tabular}




\begin{tabular}{|c|c|c|c|c|c|c|c|c|c|c|}
\hline Location & & $\begin{array}{c}\mathrm{Cr} \\
\left(\mu \mathrm{mol} \mathrm{g}{ }^{-1}\right)\end{array}$ & $\begin{array}{c}\mathrm{Ni} \\
\left(\mu \mathrm{mol} \mathrm{g}{ }^{-1}\right)\end{array}$ & $\begin{array}{c}\mathrm{Pb} \\
\left(\mu \mathrm{mol} \mathrm{g}{ }^{-1}\right)\end{array}$ & $\begin{array}{c}\mathrm{Zn} \\
\left(\mu \mathrm{mol} \mathrm{g}{ }^{-1}\right)\end{array}$ & $\begin{array}{c}\mathrm{Hg} \\
\left(\mathrm{nmol} \mathrm{g}{ }^{-1}\right)\end{array}$ & $\begin{array}{c}\mathrm{Fe} \\
\left(\mu \mathrm{mol} \mathrm{g}{ }^{-1}\right)\end{array}$ & $\begin{array}{c}\mathrm{Mn} \\
\left(\mu \mathrm{mol} \mathrm{g}{ }^{-1}\right)\end{array}$ & $\begin{array}{c}\mathrm{Cu} \\
\left(\mu \mathrm{mol} \mathrm{g}{ }^{-1}\right)\end{array}$ & $\begin{array}{c}\text { Co } \\
\left(\mu \mathrm{mol} \mathrm{g}{ }^{-1}\right)\end{array}$ \\
\hline \multirow{4}{*}{ Sinnamary } & Mean $(n=31)$ & 1.15 & 0.54 & 0.13 & 2.51 & 0.41 & 789.29 & 9.82 & $\overline{0.28}$ & 0.32 \\
\hline & SD & 0.22 & 0.10 & 0.02 & 1.08 & 0.46 & 96.43 & 9.27 & 0.10 & 0.11 \\
\hline & Max & 1.40 & 0.76 & 0.18 & 5.94 & 2.57 & 1128.57 & 45.45 & 0.61 & 0.68 \\
\hline & Min & 0.61 & 0.32 & 0.08 & 1.25 & 0.15 & 441.07 & 21.82 & 0.06 & 0.12 \\
\hline \multirow{4}{*}{ Kaw } & Mean $(n=32)$ & 1.07 & 0.60 & 0.13 & 2.66 & 0.27 & 846.43 & 9.63 & - & - \\
\hline & SD & 0.16 & 0.08 & 0.02 & 0.43 & 0.03 & 73.21 & 2.91 & - & - \\
\hline & Max & 1.29 & 0.83 & 0.27 & 4.08 & 0.33 & 1073.21 & 16.36 & - & - \\
\hline & Min & 0.76 & 0.46 & 0.08 & 1.96 & 0.23 & 712.5 & 4.36 & - & - \\
\hline \multirow{4}{*}{$\begin{array}{l}\text { Shoreface } \\
\text { sediments }\end{array}$} & Mean $(n=4)$ & 1.24 & 0.61 & 0.145 & 2.15 & 0.22 & 898.21 & 18.91 & 0.39 & 0.31 \\
\hline & SD & 0.02 & 0.03 & 0.01 & 0.23 & 0.02 & 10.71 & 0.73 & 0.03 & 0.01 \\
\hline & Max & 1.26 & 0.64 & 0.16 & 2.35 & 0.24 & 919.64 & 19.82 & 0.42 & 0.32 \\
\hline & Min & 1.22 & 0.58 & 0.13 & 1.88 & 0.19 & 887.50 & 18.18 & 0.36 & 0.31 \\
\hline \multirow[t]{4}{*}{ Amazon River* } & Mean $(n=12)$ & 1,80 & 0,72 & $0,21^{\mathrm{a}}$ & - & - & 1187,3 & - & - & 0,28 \\
\hline & SD & 0,26 & 0,13 & 0,11 & - & - & 205,11 & - & - & 0,04 \\
\hline & Max & 2,19 & 1,06 & 0,32 & - & - & 1587,72 & - & - & 0,37 \\
\hline & Min & 1,19 & 0,60 & 0,11 & - & - & 972,66 & - & - & 0,23 \\
\hline
\end{tabular}


Tab. 3

\begin{tabular}{lcccccc}
\hline & $\begin{array}{c}\mathrm{Cr} \\
\left(\mathrm{nmol} \mathrm{g}^{-1}\right)\end{array}$ & $\begin{array}{c}\mathrm{Cu} \\
\left(\mathrm{nmol} \mathrm{g}^{-1}\right)\end{array}$ & $\begin{array}{c}\mathrm{Co} \\
\left(\mathrm{nmol} \mathrm{g}^{-1}\right)\end{array}$ & $\begin{array}{c}\mathrm{Ni} \\
\left(\mathrm{nmol} \mathrm{g}^{-1}\right)\end{array}$ & $\begin{array}{c}\mathrm{Zn} \\
\left(\mathrm{nmol} \mathrm{g}^{-1}\right)\end{array}$ & $\begin{array}{c}\mathrm{Hg} \\
\left(\mathrm{nmol} \mathrm{g}^{-1}\right)\end{array}$ \\
\hline \hline Rhizizophocies leaves & 203 & 34 & 13 & 16 & - & 0.54 \\
Rhizophora stem & 219 & - & 17 & 25 & - & 0.19 \\
Avicennia leaves & 347 & 13 & 12 & 38 & 248 & 0.07 \\
Avicennia stem & 509 & 207 & 30 & 83 & 193 & 0.07 \\
Crenea leaves & 328 & 99 & 24 & 108 & 668 & 0.06 \\
Crenea stem & 346 & 87 & 10 & 37 & 1988 & 0.02 \\
Laguncularia leaves & 279 & 193 & 42 & 51 & 212 & 0.12 \\
Laguncularia stem & 151 & - & 8 & 8 & 67 & 0.12 \\
Acrostichum & 42 & 9 & 7 & 3 & 6 & 0.19 \\
\hline
\end{tabular}

